\title{
Improved Synthesis of Alkali Metal Vanadates Using a Hydrothermal Method
}

\author{
Samroeng Krachodnok ${ }^{1, a}$, Kenneth J. Haller ${ }^{1, b *}$, and Ian D. Williams ${ }^{2}$ \\ 1 School of Chemistry, Institute of Science, Suranaree University of Technology, Nakhon Ratchasima \\ 30000, Thailand \\ 2 Department of Chemistry, Hong Kong University of Science and Technology, Clear Water Bay, Kowloon, \\ Hong Kong, People's Republic of China \\ 3 Department of Applied Chemistry and Center for Innovation in Chemistry, Faculty of Science, Lampang \\ Rajabhat University, Lampang 52100, \\ Email:krachodnok@lpru.ac.tha ,ken.haller@gmail.com,*
}

\begin{abstract}
High product yield of highly crystalline layered $\mathrm{M}_{\mathrm{x}} \mathrm{V}_{3} \mathrm{O}_{8}$ compounds was obtained under hydrothermal conditions from the $\mathrm{V}_{2} \mathrm{O}_{5}-\mathrm{Zn}(\mathrm{OAc})_{2} \cdot 2 \mathrm{H}_{2} \mathrm{O}$-alkali metal salt- $\mathrm{H}_{2} \mathrm{O}$ system at significantly lower reaction temperature than previously reported in neutral media for $\mathrm{x}=1$ and $\mathrm{M}=\mathrm{K}^{+}, \mathrm{Rb}^{+}$, and $\mathrm{Cs}^{+}$, and in basic media for $\mathrm{x}=2$ and $\mathrm{M}=\mathrm{K}^{+}$. Unreacted $\mathrm{Zn}(\mathrm{OAc})_{2}$ may act as a catalyst and/or HOAc/OAc acts as a buffer in obtaining monopotassium salts while enMe used to adjust $\mathrm{pH}$ can also act as a reducing agent in producing the dipotassium salt. A new layered dipotassium zinc pyrovanadate compound, $\mathrm{K}_{2} \mathrm{ZnV}_{2} \mathrm{O}_{7}$, was formed when twice the stoichiometric ratio of the zinc salt was used. Single crystal X-ray diffraction shows the zinc compound to crystallize in the tetragonal space group $P 4_{2} / \mathrm{mnm}$ (No. 136) with $a=$ 8.3478(16) $\AA, c=11.297(3) \AA, \mathrm{V}=787.2(3) \AA^{3}$, and thus to be isomorphous with $\mathrm{K}_{2} \mathrm{MgV}_{2} \mathrm{O}_{7}$. The pentagonal-motif layer structure of $\mathrm{K}_{2} \mathrm{ZnV}_{2} \mathrm{O}_{7}$ is similar to that of $\mathrm{K}_{2}(\mathrm{VO}) \mathrm{V}_{2} \mathrm{O}_{7}$, but the unit cell parameters differ with approximate doubling of the $c$ axial length when replacing the square-pyramidal $\mathrm{VO}_{5}$ units of the $\left[\left(\mathrm{V}^{4+} \mathrm{O}\right)\left(\mathrm{V}^{5+}{ }_{2} \mathrm{O}_{7}\right)\right]_{n}{ }^{2 n-}$ layer with distorted $\mathrm{ZnO}_{4}$ tetrahedra.
\end{abstract}

Keywords: Hydrothermal synthesis, alkali metal vanadates, pentagonal-motif layers.

ENGINEERING JOURNAL Volume 16 Issue 3

Received 22 November 2011

Accepted 28 May 2012

Published 1 July 2012

Online at http://www.engj.org/

DOI:10.4186/ej.2012.16.3.19

This paper is based on the poster presentation at the German-Thai Symposium on Nanoscience and Nanotechnology 2011_Green Nanotechnology of the Future, GTSNN 2011, in Nakbon Ratchasima, Thailand, 13-16 September 2011. 


\section{Introduction}

The layered main group trivanadates $\left(\mathrm{M}_{\mathrm{x}} \mathrm{V}_{3} \mathrm{O}_{8}\right)$ are of current interest due to potential applications in Li-ion batteries [1,2] and low-temperature magnetic devices [3]. Vanadium exhibits complex structural chemistry, associated with the different valence states $(+3,+4,+5)$, coordination numbers, and geometries (tetrahedral, trigonal bipyramidal, square pyramidal, and octahedral) available to vanadium, that allows layers to be built up from different polyhedral connections and orientations. As a result, several different varieties of layered types have been reported [4-6].

Monopotassium trivanadate $\left(\mathrm{KV}_{3} \mathrm{O}_{8}\right.$ or $\left.\mathrm{K}(\mathrm{VO})_{2} \mathrm{VO}_{6}\right)$ is a member of the $\mathrm{MV}_{3} \mathrm{O}_{8}\left(\mathrm{M}=\mathrm{K}^{+}, \mathrm{Rb}^{+}, \mathrm{Cs}^{+}\right)$ family [7, 8]. Dipotassium trivanadate $\left(\mathrm{K}_{2} \mathrm{~V}_{3} \mathrm{O}_{8}\right)$ is a member of the mixed-valance fresnoite-type structure, $\left(\mathrm{M}_{2}\left(\mathrm{~V}^{4+} \mathrm{O}\right) \mathrm{V}^{5+}{ }_{2} \mathrm{O}_{7} ; \mathrm{M}=\mathrm{K}^{+}, \mathrm{Rb}^{+}, \mathrm{NH}_{4}{ }^{+}\right)$, of interest due to their low-temperature magnetic properties [3-4, 9]. This vanadate family crystallizes in the polar tetragonal space group, $P 4 \mathrm{~b} m$, and contains polymeric $\left[\left(\mathrm{V}^{4+} \mathrm{O}\right)\left(\mathrm{V}^{5+}{ }_{2} \mathrm{O}_{7}\right)\right]_{n^{2 n}}$ layers composed of equal numbers of building units of $\mathrm{V}^{4+} \mathrm{O}_{5}$ square pyramids and $\mathrm{V}^{5+}{ }_{2} \mathrm{O}_{7}$ pyrovanadates. The building units combine by corner-sharing basal $\mathrm{O}$ atoms such that all $\mathrm{V}=\mathrm{O}$ groups of the plane (and of the crystal) are oriented in the same direction parallel to the $c$ axis. Basal $\mu_{2}-\mathrm{O}$ connections form a 2-D network of pentagonal motifs. The potassium coordination environment consists of the pentagonal $\mu_{2}-\mathrm{O}$ atoms of one layer and the five associated apical $\mathrm{V}=\mathrm{O} O$ atoms of the adjacent layer giving a distorted pentagonal antiprismatic $\mathrm{KO}_{10}$ coordination environment as shown in Fig. 1 .

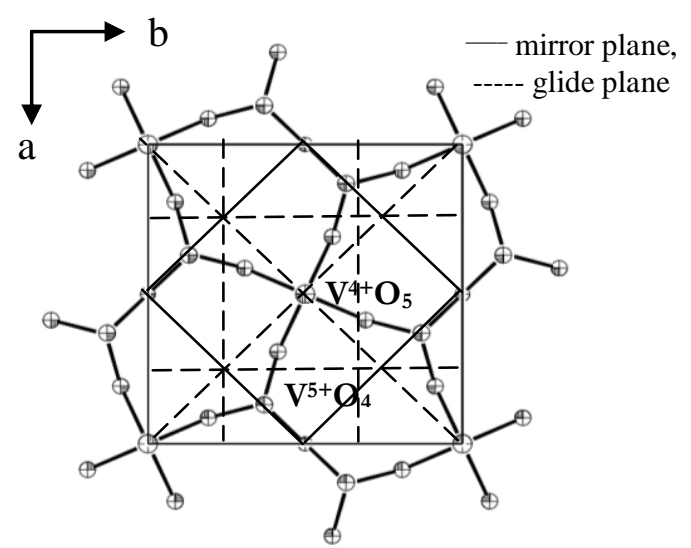

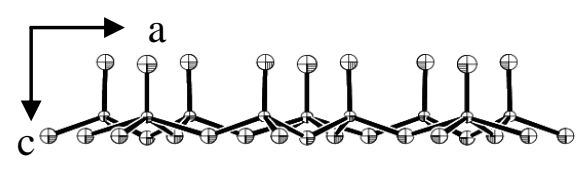

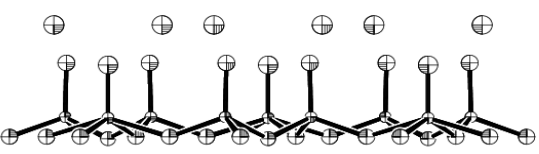

$\oplus \oplus \oplus \oplus \oplus \mathbf{K}^{+} \oplus$

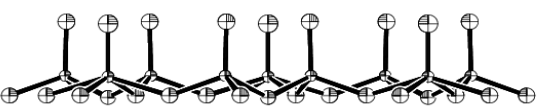

(b)

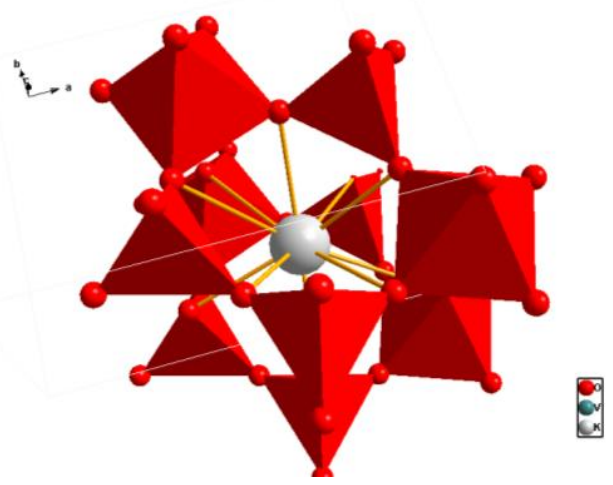

(c)

Fig. 1. Crystal structure of $\mathrm{K}_{2} \mathrm{~V}_{3} \mathrm{O}_{8}$ (a) projected onto the $a b$ plane showing the $\left[(\mathrm{VO})\left(\mathrm{V}_{2} \mathrm{O}_{7}\right]^{2-}\right.$ layer and (b) projected onto the ac plane with $\mathrm{K}^{+}$ions lying between layers, and (c) a perspective view of the pentagonal antiprismatic $\mathrm{KO}_{10}$ coordination surrounded by tetrahedral and square-pyramidal vanadium containing polyhedra [4]. (a) and (c) are in approximately the same orientation.

The melilite-type, $\mathrm{A}_{2}{ }^{+} \mathrm{B}^{2+} \mathrm{C}_{2} \mathrm{O}_{7}(\mathrm{~A}=$ alkali metal; $\mathrm{B}=$ divalent metal or similar charge, and $\mathrm{C}=$ pyrogroups), layered vanadate structures are of interest for luminescence applications $[10,11]$. They are related to the fresnoite-type structure except that the $\mathrm{B}^{2+}$ dication site forms distorted tetrahedra as compared to 
the square pyramids of the fresnoite-type structure. The $\mathrm{V}=\mathrm{O}$ groups of each $\mathrm{V}_{2} \mathrm{O}_{7}$ pyrovavadate group are oriented in opposite directions. There are two related space groups, $P-42_{1} m$ and $P 4_{2} / m n m$, in which all $\mathrm{B}^{2+} \mathrm{C}_{2} \mathrm{O}_{7}$ layers have the same vanadium polyhedra orientations and the $\mathrm{A}^{+}$monocations lie between the layers in square antiprismatic coordination environment, but the two $\mathrm{B}^{2+} \mathrm{C}_{2} \mathrm{O}_{7}$ layer types are related by mirror planes and two crystallographically independent $\mathrm{A}^{+}$form a distorted square prism, respectively. If the $\mathrm{B}^{2+}$ dication site is an alkaline earth metal, the compounds crystallize in the monoclinic space group $P 2_{1} / n$ with $\mathrm{BO}_{6}$ octahedra sharing corners with pyrovanadates forming 2-D sheets of hexagonal motifs [10]

Various synthetic conditions, including reaction temperature and $\mathrm{pH}$, and chemical sources affect the structure type of the products and thus, the intrinsic structure inside the crystal. Most trivanadates have been prepared at high temperature by ceramic synthesis routes [3-4,7-9,12-14] with difficulty in controlling the composition of the mixed-valence vanadium compounds as in the synthesis of $\mathrm{K}_{2}\left(\mathrm{~V}^{4+} \mathrm{O}\right) \mathrm{V}^{5+}{ }_{2} \mathrm{O}_{7}$. Galy and Carpy [4] obtained the single crystal product from solid state reaction of the $\mathrm{K}_{2} \mathrm{O}-\mathrm{V}_{2} \mathrm{O}_{5}-\mathrm{VO}_{2}$ system. Twenty years later, the same compound was produced from the solid state reaction of $\mathrm{KVO}_{3}, \mathrm{~V}_{2} \mathrm{O}_{3}$, and $\mathrm{V}_{2} \mathrm{O}_{5}$ in a sealed tube at $550{ }^{\circ} \mathrm{C}$ [3]. Finally, single crystals were prepared by cooling of $\mathrm{VO}_{2}$ in molten $\mathrm{KVO}_{3}$ flux in a platinum crucible sealed inside a silica container [9]. The mixed-cation pyrovanadate, $\mathrm{K}_{2} \mathrm{ZnV}_{2} \mathrm{O}_{7}$, was made by heating a 1:1:1 molar mixture of $\mathrm{K}_{2} \mathrm{CO}_{3}, \mathrm{ZnO}$, and $\mathrm{V}_{2} \mathrm{O}_{5}$ at $550{ }^{\circ} \mathrm{C}$ overnight, regrinding and heating again at $550{ }^{\circ} \mathrm{C}$ for 2 days [12].

The methods are complicated and expensive with difficulties in controlling the homogeneity, particle size, and morphology of the products. $\mathrm{KV}_{3} \mathrm{O}_{8}$ was synthesized by acidification of the corresponding metavanadate solution at near ambient temperatures of about $60-80{ }^{\circ} \mathrm{C}$, but the quality of the single crystals was not good enough [7]. Good single crystals of $\mathrm{KV}_{3} \mathrm{O}_{8}$ were synthesized in low yield by hydrothermal reaction at $250{ }^{\circ} \mathrm{C}$ of $\mathrm{V}_{2} \mathrm{O}_{5}$ powder with alkali metal nitrate, chloride, and sulfate solution [8], later $\mathrm{K}_{2} \mathrm{~V}_{3} \mathrm{O}_{8}$ nanorods were prepared in low yield under solvothermal conditions at $200{ }^{\circ} \mathrm{C}$ employing a reducing agent and ethanol as a solvent [13], and still later tubular-windows on sheet-like $\mathrm{K}_{2} \mathrm{~V}_{3} \mathrm{O}_{8}$ single crystals were prepared in pure phase under hydrothermal conditions from $\mathrm{KVO}_{3}-\mathrm{KOH}$-apidic acid as a mild reducing agent, buffer, and a potentially morphological directing agent at $180{ }^{\circ} \mathrm{C}$ for 2 days [14].

This work follows up on our previous report from a similar reaction system [15] where the diamines incorporate into hybrid zinc-vanadium products. Herein we report a high yield hydrothermal synthesis of highly crystalline $\mathrm{M}_{x} \mathrm{~V}_{3} \mathrm{O}_{8}$. Reaction conditions were varied and enMe was used to adjust reaction $\mathrm{pH}$ and as a reducing agent. $\mathrm{Zn}(\mathrm{OAc})_{2}$ employed as a potential catalyst in the formation of $\mathrm{M}_{\mathrm{x}} \mathrm{V}_{3} \mathrm{O}_{8}$ also became a $\mathrm{Zn}^{2+}$ source to replace $\mathrm{VO}^{2+}$ ions forming $\mathrm{K}_{2} \mathrm{ZnV}_{2} \mathrm{O}_{7}$ as a product.

\section{Experimental}

\subsection{Chemicals and Instrumentation}

All reagents were used as received. All syntheses were carried out in PTFE-lined stainless steel reactors under autogenous pressure. The $23 \mathrm{~mL}$ reaction vessels were filled to approximately $40 \%$ volume capacity. Powder X-ray diffraction patterns were recorded on a Philips PW1830 diffractometer equipped with a Cu $\mathrm{Ka} \mathrm{X}$-ray source $(\bar{\lambda}=1.54062 \AA)$ in the angular range $2 \theta=5-50^{\circ}$, with $0.05^{\circ}$ step size and $3 \mathrm{~s}$ per step counting time. XRD pattern analyses were carried out by the Traces program version 3 . Single crystal X-ray diffraction characterization utilized a Bruker Smart Apex CCD diffractometer equipped with a graphitemonochromated Mo Ka X-radiation source $(\bar{\lambda}=0.71073 \AA)$ and standard Bruker software [16]. Infrared spectra of the samples were recorded using pressed $\mathrm{KBr}$ pellets on a Perkin-Elmer Spectrum GX FTIR spectrophotometer in the range of $650-1100 \mathrm{~cm}^{-1}\left(5\right.$ scans, resolution $\left.4 \mathrm{~cm}^{-1}\right)$.

\subsection{Synthesis of Monopotassium (or Rubidium or Cesium) Trivanadates, $\mathrm{MV}_{3} \mathrm{O}_{8}$}

$\mathrm{V}_{2} \mathrm{O}_{5}(181 \mathrm{mg}), \mathrm{Zn}(\mathrm{OAc})_{2} \cdot 2 \mathrm{H}_{2} \mathrm{O}(220 \mathrm{mg}), \mathrm{KOH}(56 \mathrm{mg})$ or $\mathrm{RbCl}(121 \mathrm{mg})$ or $\mathrm{CsCl}(168 \mathrm{mg})$, and water $(2.0 \mathrm{~mL})$, mole ratio 1:1:1:111 were heated at 110,160 , and $200{ }^{\circ} \mathrm{C}$ for 2 days. Initial and final reaction $\mathrm{pH}$ was $\sim 7$ without adjustment. Orange plates of $\mathrm{AV}_{3} \mathrm{O}_{8}$ were isolated with product yields as in Table 1. Selected FT-IR bands $\left(\mathrm{cm}^{-1}\right)$ : $\mathrm{KV}_{3} \mathrm{O}_{8}, 990$ (w), 959 (s) and 737 (br); $\mathrm{RbV}_{3} \mathrm{O}_{8}, 1005$ (m), 967 (s, sh) and 780 (sh), and 737 (br); and $\mathrm{CsV}_{3} \mathrm{O}_{8}, 1000$ (m), 963 (s), 783 (sh), and 741 (br). 
Table 1. Product Yields of $\mathrm{M}_{\mathrm{x}} \mathrm{V}_{3} \mathrm{O}_{8}$ (Based on $\left.\mathrm{V}_{2} \mathrm{O}_{5}\right)$ as a Function of Temperature.

\begin{tabular}{cccc}
\hline \multirow{2}{*}{ Compound } & \multicolumn{3}{c}{ Reaction Temperature } \\
\cline { 2 - 4 } & $110{ }^{\circ} \mathrm{C}$ & $160{ }^{\circ} \mathrm{C}$ & $200{ }^{\circ} \mathrm{C}$ \\
\hline $\mathrm{KV}_{3} \mathrm{O}_{8}$ & $66 \%$ & $87 \%$ & $90 \%$ \\
$\mathrm{RbV}_{3} \mathrm{O}_{8}$ & $86 \%$ & $88 \%$ & $90 \%$ \\
$\mathrm{CsV}_{3} \mathrm{O}_{8}$ & $91 \%$ & $94 \%$ & $100 \%$ \\
$\mathrm{~K}_{2} \mathrm{~V}_{3} \mathrm{O}_{8}$ & $60 \%$ & $80 \% \mathrm{a}$ & $40 \%{ }^{\mathrm{b}}$ \\
$\mathrm{K}_{2} \mathrm{ZnV}_{2} \mathrm{O}_{7}$ & $5 \%$ & & \\
\hline
\end{tabular}

a Reaction temperature for $\mathrm{K}_{2} \mathrm{~V}_{3} \mathrm{O}_{8}$ of $140{ }^{\circ} \mathrm{C}$.

b The yield of $\mathrm{K}_{2} \mathrm{~V}_{3} \mathrm{O}_{8}$ for reaction temperature of $180{ }^{\circ} \mathrm{C}$ was $50 \%$.

\subsection{Synthesis of Dipotassium Trivanadate, $\mathrm{K}_{2} \mathrm{~V}_{3} \mathrm{O}_{8}$}

$\mathrm{V}_{2} \mathrm{O}_{5}(181 \mathrm{mg}), \mathrm{Zn}(\mathrm{OAc})_{2} \cdot 2 \mathrm{H}_{2} \mathrm{O}(220 \mathrm{mg}), \mathrm{KOH}(56 \mathrm{mg})$, and water $(2.0 \mathrm{~mL})$, mole ratio 1:1:1:111 were heated at $110{ }^{\circ} \mathrm{C}$ for 2 days. Initial reaction $\mathrm{pH}$ was adjusted to $\sim 11$ with enMe. Final reaction $\mathrm{pH}$ was $\sim 9$. Black plates of $\mathrm{K}_{2} \mathrm{~V}_{3} \mathrm{O}_{8}$ (yield $\sim 60 \%$, based on $\mathrm{V}_{2} \mathrm{O}_{5}$ ) were obtained as the major product with a small amount of black powder, (HenMe) $\mathrm{ZnV}_{8} \mathrm{O}_{20}$ [15], as a minor product. The highest product yield $(\sim 80 \%$, based on $\mathrm{V}_{2} \mathrm{O}_{5}$ ) was obtained by increasing reaction temperature to $140{ }^{\circ} \mathrm{C}$. The yield decreased with increasing reaction temperature above $140{ }^{\circ} \mathrm{C}$ (yield $\sim 40 \%$ at $200{ }^{\circ} \mathrm{C}$ ). Selected FT-IR bands $\left(\mathrm{cm}^{-1}\right)$ : 991 (m), $940(\mathrm{w}), 926(\mathrm{vw}), 817(\mathrm{br})$ and $740(\mathrm{br})$.

\subsection{Synthesis of Dipotassium Zinc Pyrovanadate, $\mathrm{K}_{2} \mathrm{ZnV}_{2} \mathrm{O}_{7}$}

Procedure similar to that for $\mathrm{K}_{2} \mathrm{~V}_{3} \mathrm{O}_{8}$ except twice the stoichiometric amount of $\mathrm{Zn}(\mathrm{OAc})_{2} \cdot 2 \mathrm{H}_{2} \mathrm{O}(2.0$ mmol) was used. Heating at $110{ }^{\circ} \mathrm{C}$ for 2 days gave a mixture of black plates of $\mathrm{K}_{2} \mathrm{~V}_{3} \mathrm{O}_{8}$, black blocks of $\mathrm{Zn}(\mathrm{HenMe})_{2} \mathrm{~V}_{8} \mathrm{O}_{20}$, and colorless needles of $\mathrm{K}_{2} \mathrm{ZnV}_{2} \mathrm{O}_{7}$ with yields of $\sim 60 \%, \sim 35 \%$, and $\sim 5 \%$, respectively, based on $\mathrm{V}_{2} \mathrm{O}_{5}$. Selected FT-IR bands ( $\left.\mathrm{cm}^{-1}\right)$ : 936 (br), 896 (br), 851 (br) and 691 (br).

\subsection{X-ray Crystallography}

A single crystal of $\mathrm{K}_{2} \mathrm{ZnV}_{2} \mathrm{O}_{7}$ suitable for single-crystal X-ray diffraction with size $0.01 \times 0.01 \times 0.30 \mathrm{~mm}$ was used. Unit cell parameters and space group were determined by standard procedures [16] from data collected on a Bruker Smart Apex CCD diffractometer at $100 \pm 2 \mathrm{~K}$. Crystal data are given in Table 2. The new compound is isomorphous with $\mathrm{K}_{2} \mathrm{MgV}_{2} \mathrm{O}_{7}$ [17].

Table 2. Crystal Data for $\mathrm{K}_{2} \mathrm{ZnV}_{2} \mathrm{O}_{7}$.

\begin{tabular}{|c|c|}
\hline \multicolumn{2}{|c|}{ Crystal Data for $\mathrm{K}_{2} \mathrm{ZnV}_{2} \mathrm{O}_{7}$} \\
\hline Chemical formula & $\mathrm{K}_{2} \mathrm{O}_{7} \mathrm{~V}_{2} \mathrm{Zn}$ \\
\hline $\mathrm{M}_{\mathrm{r}}$ (Daltons) & 178.72 \\
\hline Temperature (K) & $100 \pm 2$ \\
\hline Crystal system, space group & Tetragonal, $P 4_{2} / \mathrm{mnm}$ \\
\hline Unit cell parameters: $a,(\AA)$ & $8.3478(16)$ \\
\hline$c,(\AA)$ & $11.297(3)$ \\
\hline$V,\left(\AA^{3}\right)$ & $787.2(3)$ \\
\hline$Z$ & 2 \\
\hline$D_{\text {calc }}\left(\mathrm{Mg} \mathrm{m}^{-3}\right)$ & 1.508 \\
\hline
\end{tabular}




\section{Results and Discussion}

\subsection{Hydrothermal Synthesis}

Four $\mathrm{M}_{\mathrm{x}} \mathrm{V}_{3} \mathrm{O}_{8}$ compounds were synthesized using water as an environmentally friendly solvent in the hydrothermal reaction of $\mathrm{V}_{2} \mathrm{O}_{5}$ and $\mathrm{Zn}(\mathrm{OAc})_{2} \cdot 2 \mathrm{H}_{2} \mathrm{O}$ with alkali metal sources $(\mathrm{KOH}, \mathrm{RbCl}, \mathrm{CsCl})$ in the mole ratio of 1:1:1 in 2-day reactions. Previous work had found that both reaction $\mathrm{pH}$ and temperature play crucial roles in determining the isolated solid product [18], and that the nature of organic sources and solvent could lead to reduction of oxidation state of the transition metal and/or control of size and morphology of the crystal products $[13,14]$. With $\mathrm{x}=1$ and $\mathrm{M}=\mathrm{K}^{+}, \mathrm{Rb}^{+}, \mathrm{Cs}^{+}$, orange plates were formed in neutral media at $110{ }^{\circ} \mathrm{C}$ without an organic source, whereas for $\mathrm{x}=2$ and $\mathrm{M}=\mathrm{K}^{+}$, phase-pure black plates, similar to those of [14], were isolated from basic media at $140{ }^{\circ} \mathrm{C}$, using an organic base (enMe) to adjust $\mathrm{pH}$ and act as a reducing agent. Acetic acid/acetate in this work may be similar to apidic acid/apidate in [14] which is suggested to act as a buffer. The acidic aqueous solvent gives plate morphology, compared to the nanorods obtained under solvothermal reaction conditions employing ethanol as solvent and reducing agent [13]. While the organic reactants and solvent are crucial factors, vanadium oxide sources seem to have no effect on the size and morphology of the product (including acidity with $\mathrm{V}_{2} \mathrm{O}_{5}$ observed herein and previously [13] and basicity with $\mathrm{KVO}_{3}$ [14]). Zinc acetate acts as a good catalyst in the formation of $\mathrm{K}_{2} \mathrm{~V}_{3} \mathrm{O}_{8}$ with relatively higher yield than previously obtained, but with the yield limited due to $\mathrm{Zn}^{2+}$ competing with $\mathrm{VO}^{2+}$ ions forming $\mathrm{K}_{2} \mathrm{ZnV}_{2} \mathrm{O}_{7}$ with increasing amounts of $\mathrm{Zn}(\mathrm{OAc})_{2} \cdot 2 \mathrm{H}_{2} \mathrm{O}$.

\subsection{XRD patterns}

Experimental XRD patterns of bulk samples of all compounds are compared to the simulated XRD patterns calculated from previously reported single crystal X-ray structural results [8] in Fig. 2. The patterns indicate highly crystalline pure phase products at all reaction temperatures with increasing crystallinity, as shown by increasing intensity and sharpening of the XRD peaks [2], as reaction temperature increases.

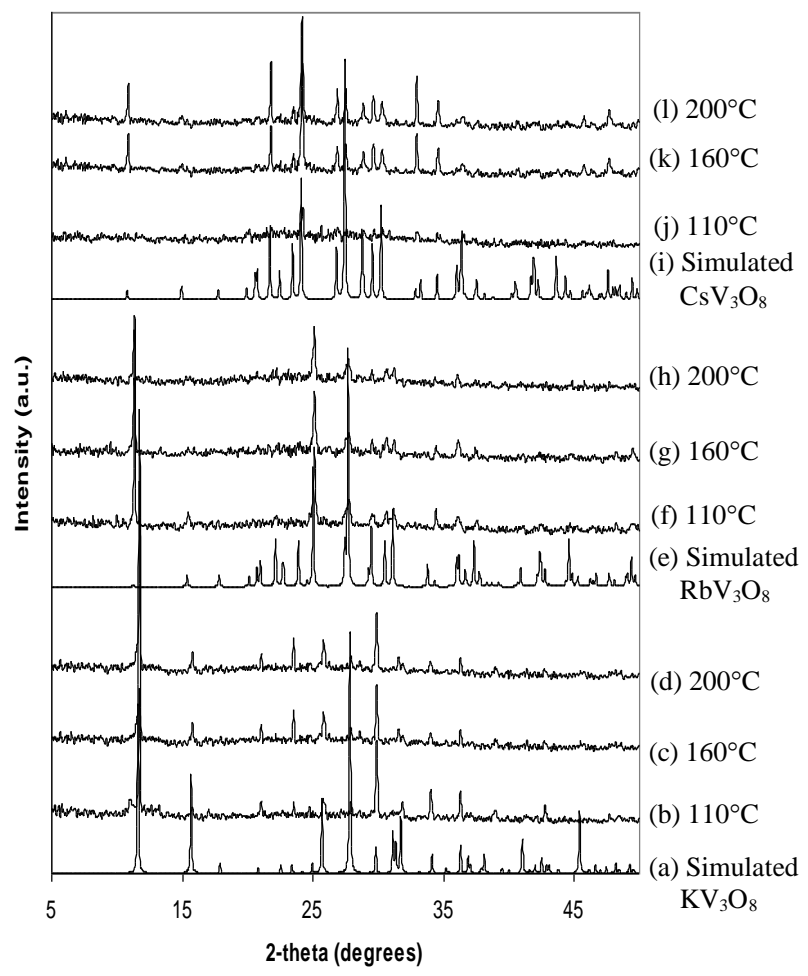

(a) $\mathrm{MV}_{3} \mathrm{O}_{8}$

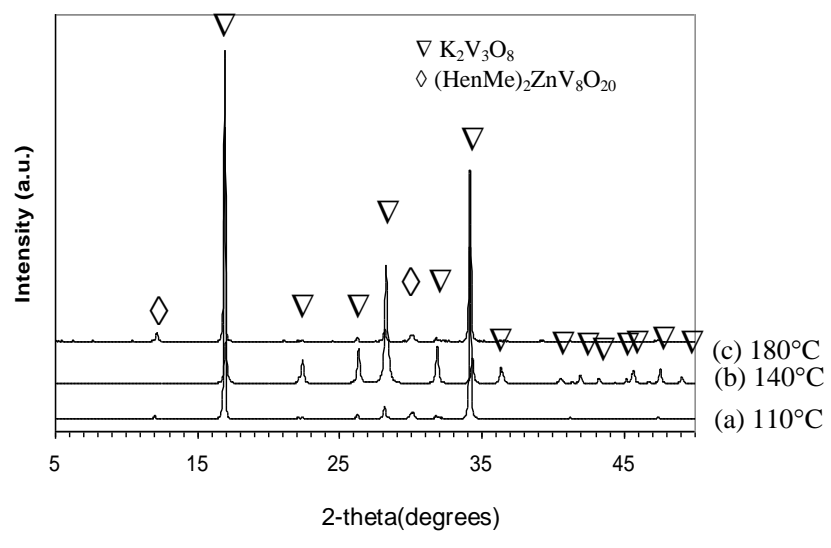

(b) $\mathrm{K}_{2} \mathrm{~V}_{3} \mathrm{O}_{8}$

Fig. 2. Simulated and experimental XRD patterns for $\mathrm{MV}_{3} \mathrm{O}_{8}$ and $\mathrm{K}_{2} \mathrm{~V}_{3} \mathrm{O}_{8}$. 
The XRD patterns of $\mathrm{MV}_{3} \mathrm{O}_{8}$ (Fig. 2(a)) also show highest crystallity for the $\mathrm{MV}_{3} \mathrm{O}_{8}$ phase at $200{ }^{\circ} \mathrm{C}$. Fewer diffraction peaks are observed for $\mathrm{RbV}_{3} \mathrm{O}_{8}$ and $\mathrm{CsV}_{3} \mathrm{O}_{8}$ relative to $\mathrm{KV}_{3} \mathrm{O}_{8}$, indicating lower crystallity in spite of the higher yields of $86 \%$ and $91 \%$, respectively, even at $110{ }^{\circ} \mathrm{C}$. Unreacted zinc acetate may possibly act as a catalyst [19], significantly reducing reaction temperature to near $100{ }^{\circ} \mathrm{C}$ for obtaining $\mathrm{MV}_{3} \mathrm{O}_{8}$ compounds as reported herein compared to $250{ }^{\circ} \mathrm{C}$ reported previously [8].

The XRD patterns of $\mathrm{K}_{2} \mathrm{~V}_{3} \mathrm{O}_{8}$ (Fig. 2(b)) also show highly crystalline phase $\mathrm{K}_{2} \mathrm{~V}_{3} \mathrm{O}_{8}$ at the optimum reaction temperature of $140{ }^{\circ} \mathrm{C}$ ( $\sim 80 \%$ yield), significantly lower by $40{ }^{\circ} \mathrm{C}$ compared to the previous hydrothermal reaction in slightly acidic ( $\mathrm{pH} 4.5-6)$ solution [14] and by $60{ }^{\circ} \mathrm{C}$ compared to the solvothermal reaction [13]. Unreacted zinc acetate is presumed to act as a catalyst [19] as noted above. At lower or higher reaction temperatures than at $140{ }^{\circ} \mathrm{C}$, black crystals of the 3-D nanoporous material (HenMe) ${ }_{2} \mathrm{ZnV}_{8} \mathrm{O}_{20}$ [15], were also formed.

\subsection{The Crystal Structure of $\mathrm{K}_{2} \mathrm{ZnV}_{2} \mathrm{O}_{7}$}

Single crystal X-ray diffraction shows $\mathrm{K}_{2} \mathrm{ZnV}_{2} \mathrm{O}_{7}$ to be isomorphous to $\mathrm{K}_{2} \mathrm{MgV}_{2} \mathrm{O}_{7}$ [17] with tetragonal space group $P_{2} /$ mnm (No. 136). The $c$ axis length is double that of $\mathrm{K}_{2} \mathrm{~V}_{3} \mathrm{O}_{8}$, space group P4bm, consistent with the existence of the mirror plane perpendicular to the [001] direction between two $\left[\mathrm{BV}_{2} \mathrm{O}_{7}\right]_{n}{ }^{2 n-}$ layers ( $\mathrm{B}=\mathrm{Mg}$ in [17] and $\mathrm{Zn}$ herein). The structure contains $\left[\mathrm{ZnV}_{2} \mathrm{O}_{7}\right]_{n}{ }^{2 n-}$ layers with $\mathrm{K}^{+}$positioned between the layers forming two unique distorted square-prismatic $\mathrm{KO}_{8}$ coordination environments as can be seen in Fig. 3.

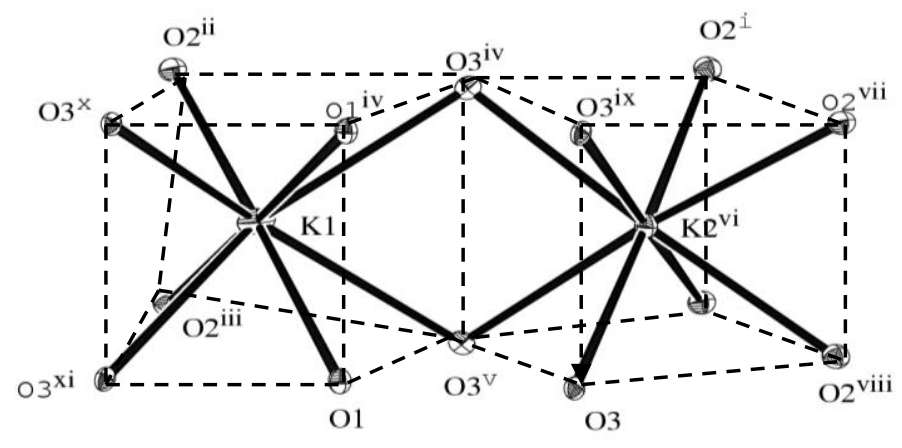

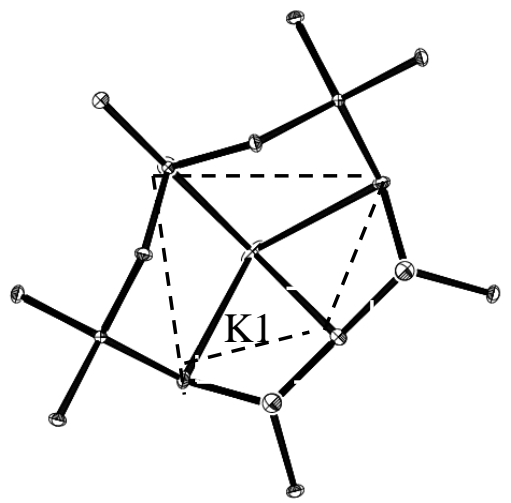

(b)

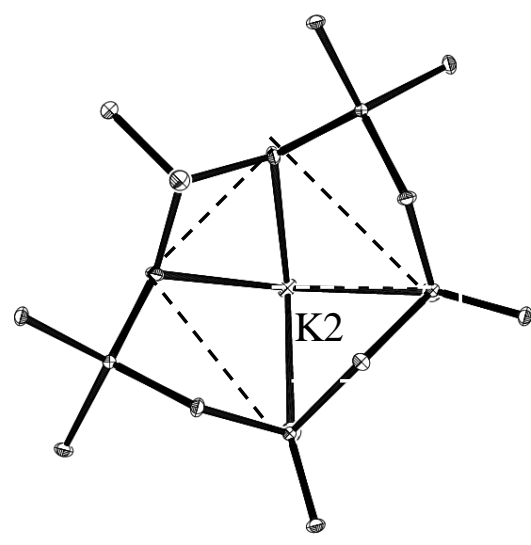

(c)

Fig. 3. (a) Perspective view of the distorted square prismatic environments of the $\mathrm{K}^{+}$ions and projection views of (b) $\mathrm{K}(1)$ and (c) $\mathrm{K}(2)$ in the centers of the pentagonal channels in $\mathrm{K}_{2} \mathrm{ZnV}_{2} \mathrm{O}_{7}$.

The layer consists of equal numbers of the two building units; the tetrahedral $\mathrm{ZnO}_{4}$ units lying on -4 sites at $0,1 / 2, \mathrm{z}$ and $1 / 2,0, \mathrm{z}\left(\mathrm{z}=1 / 4\right.$ and $\left.{ }^{3} / 4\right)$ and $\mathrm{V}_{2} \mathrm{O}_{7}$ units positioned on $2 . \mathrm{mm}$ sites similar to those observed in $\mathrm{K}_{2} \mathrm{~V}_{3} \mathrm{O}_{8}$ (Fig. 4(d)) except the $\mathrm{V}=\mathrm{O}$ groups of pyrovanadate units are oriented in opposite directions while they are oriented in the same direction in $\mathrm{K}_{2} \mathrm{~V}_{3} \mathrm{O}_{8}$. The interlayer spacing is $3.230 \AA$ and similar to that observed in $\mathrm{K}_{2} \mathrm{MgV}_{2} \mathrm{O}_{7}$ [17], but larger than the $3.055 \AA$ in $\mathrm{K}_{2}(\mathrm{VO}) \mathrm{V}_{2} \mathrm{O}_{7}$ [20] and smaller than the $3.477 \AA$ in $\mathrm{Rb}_{2} \mathrm{MnV}_{2} \mathrm{O}_{7}$ and the $3.444 \AA$ in $\mathrm{KRbMnV}_{2} \mathrm{O}_{7}$ [21]. The $\mathrm{O}-\mathrm{Zn}-\mathrm{O}$ angles of $114.25(13)^{\circ}$ 
show smaller deviation from normal tetrahedral geometry compared to the $\mathrm{O}-\mathrm{Mn}-\mathrm{O}$ angles, 121.05(7), 117.4(2) $)^{\circ}$, $115.63(19)^{\circ}$, and $115(1)^{\circ}$, in $\mathrm{K}_{2} \mathrm{MnV}_{2} \mathrm{O}_{7}, \mathrm{Rb}_{2} \mathrm{MnV}_{2} \mathrm{O}_{7}, \mathrm{KRbMnV}_{2} \mathrm{O}_{7}$, and $\mathrm{K}_{2} \mathrm{MnV}_{2} \mathrm{O}_{7}$, respectively. The $\mathrm{V}-\mathrm{O}$ bond distances and the $\mathrm{O}-\mathrm{V}-\mathrm{O}$ angles are in the normal range, similar to those observed in $\mathrm{Rb}_{2} \mathrm{MnV}_{2} \mathrm{O}_{7}$ and $\mathrm{KRbMnV}_{2} \mathrm{O}_{7}$.

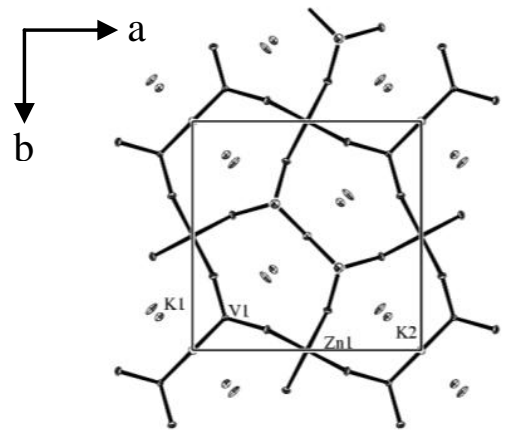

(a)

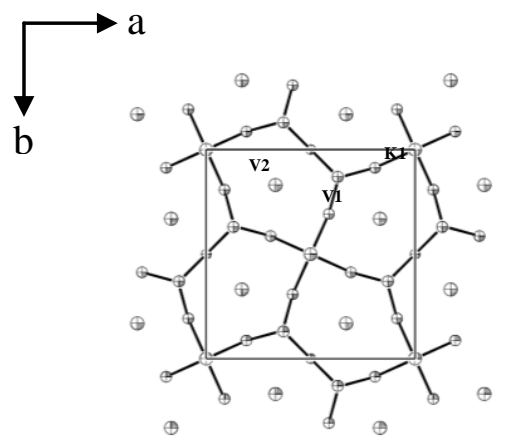

(c)

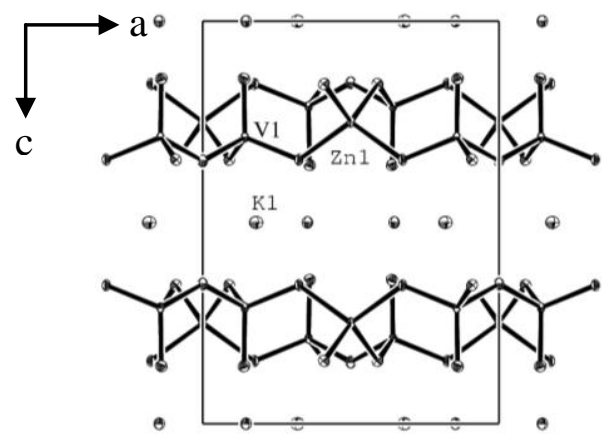

(b)

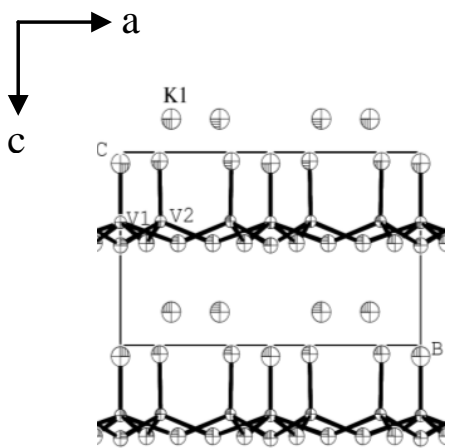

(d)

Fig. 4. Comparing the $\left[\mathrm{ZnV}_{2} \mathrm{O}_{7}\right]^{2-}$ layer (a) projected onto the $a b$ plane and (b) on the $a c$ plane, with the $\left[\left(\mathrm{V}^{4+} \mathrm{O}\right) \mathrm{V}_{2} \mathrm{O}_{7}\right]^{2-}$ layer (c) projected onto the $a b$ plane and (d) on the $a c$ plane; after [20].

\subsection{Infrared Spectroscopy}

Figure 5 shows FT-IR spectra of the vanadates. The spectrum of $\mathrm{CsV}_{3} \mathrm{O}_{8}$ has medium and strong absorption peaks at 1000 and $963 \mathrm{~cm}^{-1}$ due to the vibration modes of two distinct $\mathrm{V}=\mathrm{O}$ units. While the shorter $\mathrm{V}=\mathrm{O}$ bond, at axial position of $\mathrm{V}^{5+} \mathrm{O}_{6}$ octahedra has $\mathrm{d}[\mathrm{V}=\mathrm{O}(1)]=1.599(9) \AA$ and the longer bonds at apical positions of $\mathrm{V}^{5+} \mathrm{O}_{5}$ square pyramids have $\mathrm{d}[\mathrm{V}=\mathrm{O}(4)]=1.602(7) \AA$, this slight difference in distance, $0.003 \AA$, is not statistically significant. The significantly different distances involve $\mathrm{V}=\mathrm{O} \mathrm{O}$ atoms connecting to the $\mathrm{MO}_{8}$ coordination motif where $\mathrm{d}[\mathrm{K}-\mathrm{O}(1)]=3.093(9) \AA$, with a shorter distance of 0.006 and $0.105 \AA$ compared to other $\mathrm{d}[\mathrm{K}-\mathrm{O}(4)]=3.098(6)$ and $3.197(6) \AA$, respectively. Comparing these IR peaks with those of isostructural compounds; 1005 and $967 \mathrm{~cm}^{-1}$ for $\mathrm{Rb}$, and 990 and $959 \mathrm{~cm}^{-1}$ for $\mathrm{K}$, suggest the $\mathrm{V}=\mathrm{O}$ bond distance of $\mathrm{CsV}_{3} \mathrm{O}_{8}$ is shorter than in $\mathrm{KV}_{3} \mathrm{O}_{8}$ and longer than $\mathrm{RbV}_{3} \mathrm{O}_{8}$, not in agreement with those observed by Oka et al. [8]. The broad absorption peak near $740 \mathrm{~cm}^{-1}$, and the shoulders near $780 \mathrm{~cm}^{-1}$ are assigned to the antisymmetric stretching and bending modes of the $\mathrm{V}-\mathrm{O}_{\mathrm{b}}$ bond and $\mathrm{V}-\mathrm{O}-\mathrm{V}$ bridges, however, it is very difficult to correlate and classify the $\mathrm{O}_{\mathrm{b}}$ bond, where $\mathrm{b}$ are bridging $\mathrm{O}$ atoms, with bending modes from infrared spectroscopy.

For $\mathrm{K}_{2} \mathrm{~V}_{3} \mathrm{O}_{8}$, the strong and very weak absorption peaks at 991 and $940 \mathrm{~cm}^{-1}$ are assigned to the vibrational modes of two $\mathrm{V}=\mathrm{O}$ bonds at apical positions of $\mathrm{V}^{4+} \mathrm{O}_{5}$ square pyramid and $\mathrm{V}^{5+} \mathrm{O}_{4}$ tetrahedra along the $c$ axis, $d\left[V=\mathrm{O}_{\mathrm{t}}\right]=1.582(6)$ and 1.628(11) $\AA$, respectively, due to the five associated apical $\mathrm{V}=\mathrm{O} \mathrm{O}$ atoms of pentagonal antiprismatic $\mathrm{KO}_{10}$ coordination environment. There are three shorter bonds, $\mathrm{d}[\mathrm{K}-\mathrm{O}]$ $=2.769(11)$ and 2.904(11) $\AA$ and one longer bond, $\mathrm{d}[\mathrm{K}-\mathrm{O}]=3.512(6) \AA$, related to apical positions of square pyramids and tetrahedra, respectively. Three absorption peaks at 926,817 , and $740 \mathrm{~cm}^{-1}$ are assigned to the antisymmetric stretching and bending modes of bridging $\mathrm{V}-\mathrm{O}_{\mathrm{b}}-\mathrm{V}$ units related to the 2-D vanadium and basal-plane oxygen atoms in the ab plane $[4,9,14,20]$. 
The broad bands at 936, 896 and $851 \mathrm{~cm}^{-1}$ in the IR spectrum of $\mathrm{K}_{2} \mathrm{ZnV}_{2} \mathrm{O}_{7}$ correspond to the vanadate bonds with distances of 1.643(3), 1.707(2) and 1.806(2) $\AA$ [22], and the broad peak at $691 \mathrm{~cm}^{-1}$ is assigned to the bending mode of the bridging $\mathrm{V}-\mathrm{O}_{\mathrm{b}}-\mathrm{V}$ units.

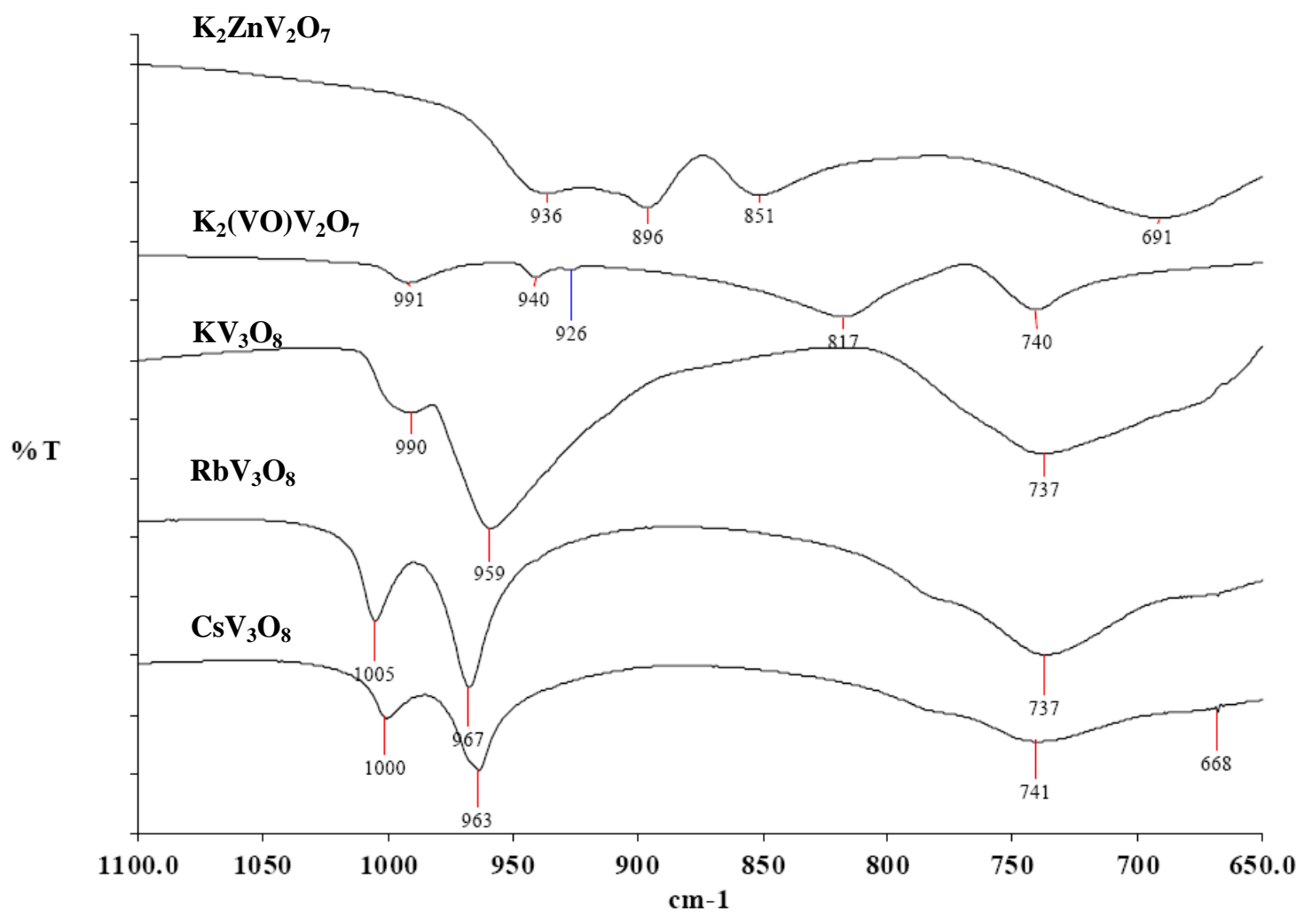

Fig. 5. FT-IR spectra of alkali metal vanadates.

\section{Conclusions}

Four layered trivanadate compounds have been prepared in high yield by hydrothermal synthesis from $\mathrm{V}_{2} \mathrm{O}_{5}$ and $\mathrm{KOH}$ in mole ratio 1:1 $\left(\mathrm{MV}_{3} \mathrm{O}_{8}, \mathrm{M}=\mathrm{K}, \mathrm{Rb}\right.$, and $\mathrm{Cs}$, in neutral media, and mixed valence $\mathrm{K}_{2} \mathrm{~V}_{3} \mathrm{O}_{8}$ in basic media) with reaction temperature lower than previous reports due to zinc acetate possibly acting as catalyst and enMe, in the latter case, as a reductant to reduce $\mathrm{V}^{5+}$ to $\mathrm{V}^{4+}$ as well as in ethanol. The new mixed cation pyrovanadate, $\mathrm{K}_{2} \mathrm{ZnV}_{2} \mathrm{O}_{7}$, formed as a competing product when the quantity of zinc acetate catalyst was increased. This simple, inexpensive, and environmentally friendly hydrothermal preparation route can be developed to prepare other layered vanadates systems.

\section{References}

[1] G. Li, S. Pang, L. Jiang, Z. Guo, and Z. Zhang, "Environmentally friendly chemical route to vanadium oxide single-crystalline nanobelts as a cathode material for lithium-ion batteries," J. Phys. Chem. B, vol. 110, no. 19, pp. 9383-9386, 2006.

[2] H. Yang, J. Li, X.-G. Zhang, and Y.-L. Jin, "Synthesis of $\mathrm{LiV}_{3} \mathrm{O}_{8}$ nanocrystallites as cathode materials for lithium ion batteries," J. Mat. Process. Tech., vol. 207, no. 1-3, pp. 265-270, 2008.

[3] G. Liu and J. E. Greedan, "Magnetic properties of fresnoite-type vanadium oxides: $\mathrm{A}_{2} \mathrm{~V}_{3} \mathrm{O}_{8}(\mathrm{~A}=\mathrm{K}$, $\left.\mathrm{Rb}, \mathrm{NH}_{4}\right)$," J. Solid State Chem., vol. 114, no. 1, pp. 499-505, 1995.

[4] J. Galy and A. Carpy, "Structure crystalline de $\mathrm{K}_{2} \mathrm{~V}_{3} \mathrm{O}_{8}$ ou $\mathrm{K}_{2}(\mathrm{VO})\left[\mathrm{V}_{2} \mathrm{O}_{7}\right]$," Acta Cryst. Sect. B, vol. 31, no. 6, pp. 1794-1795, 1975.

[5] D. Riou and G. Férey, "Intercalated vanadyl vanadates: syntheses, crystal structures, and magnetic properties," Inorg. Chem, vol. 34, no. 26, pp. 6520-6523, 1995.

[6] Y. Zhang, R. C. Haushalter, and A. Clearfield, "Hydrothermal syntheses and structural characterization of layered vanadium oxides incorporating organic cations: $a-, \beta$ - 
$\left(\mathrm{H}_{3} \mathrm{~N}\left(\mathrm{CH}_{2}\right)_{2} \mathrm{NH}_{3}\right)\left[\mathrm{V}_{4} \mathrm{O}_{10}\right]$ and $a-, \beta-\left(\mathrm{H}_{2} \mathrm{~N}\left(\mathrm{C}_{2} \mathrm{H}_{4}\right)_{2} \mathrm{NH}_{2}\right)\left[\mathrm{V}_{4} \mathrm{O}_{10}\right]$," Inorg. Chem., vol. 35, no. 17, pp. 49504956, 1996.

[7] H. T. Evans and S. Block, "The crystal structures of potassium and cesium trivanadates," Inorg. Chem., vol. 5, no. 10, pp. 1808-1814, 1966.

[8] Y. Oka, T. Yao, and N. Yamamoto, "Hydrothermal synthesis and structure refinements of alkalimetal trivanadates $\mathrm{MV}_{3} \mathrm{O}_{8}(\mathrm{M}=\mathrm{K}, \mathrm{Rb}, \mathrm{Cs})$," Mat. Res. Bull., vol. 32, no. 9, pp. 1201-1209, 1997.

[9] L. Choi, Z. T. Zhu, J. L. Musfeldt, G. Ragghianti, D. Mandrus, B. C. Sales, and J. R. Thompson, "Local symmetry breaking in $\mathrm{K}_{2} \mathrm{~V}_{3} \mathrm{O}_{8}$ as studied by infrared spectroscopy," Phys. Rev. B, vol. 65, no. 5, pp. 54101-54106, 2001.

[10] V. G. Zubkov, A. P. Tyutyunnik, N. V. Tarakina, I. F. Berger, L. L. Surat, B. V. Slobodin, G. Svensson, B. Forslund, B. V. Shulgin, V. A. Pustovarov, A. V. Ishchenko, and A. N. Cherepanov, "Synthesis, crystal structure and luminescent properties of pyrovanadates $\mathrm{M}_{2} \mathrm{CaV}_{2} \mathrm{O}_{7}(\mathrm{M}=\mathrm{Rb}, \mathrm{Cs})$," Solid State Sci., vol. 11, no. 3, pp. 726-732, 2009.

[11] B. V. Slobodin, L. L. Surat, R. F. Samigullina, A. V. Ishchenko, B. V.,Shulgin, and A. N. Cherepanov, "Thermochemical and luminescent properties of the $\mathrm{K}_{2} \mathrm{MgV}_{2} \mathrm{O}_{7}$ and $\mathrm{M}_{2} \mathrm{CaV}_{2} \mathrm{O}_{7}(\mathrm{M}=\mathrm{K}, \mathrm{Rb}, \mathrm{Cs})$ vanadates," Inorg. Mat., vol. 46, no. 5, pp. 522-528, 2010.

[12] H. McMurdie, M. Morris, E. Evans, B. Paretzkin, W. Wong-Ng, and Y. Zhang, "Standard x-ray diffraction powder patterns from the JCPDS Research Associateship," Powder Diffraction, vol. 1, no. 4, p. $343,1986$.

[13] H. Xu, W. He, H. Wang, and H. Yan, "Solvothermal synthesis of $\mathrm{K}_{2} \mathrm{~V}_{3} \mathrm{O}_{8}$ nanorods," J. Cryst. Growth, vol. 260, no. 3, pp. 447-450, 2004.

[14] F.-N. Shi, J. Rocha, A. B. Lopes, and T. Trindade, "Morphological micro-patterning of tubularwindows on crystalline $\mathrm{K}_{2} \mathrm{~V}_{3} \mathrm{O}_{8}$ sheets," J. Cryst. Growth, vol. 273, no. 3-4, pp. 572-576, 2005.

[15] S. Krachodnok, K. J. Haller, and I. D. Williams, "Hydrothermal synthesis of three-dimensional nanoporous zinc vanadates: (HenMe) ${ }_{2} \mathrm{ZnV}^{4+}{ }_{4} \mathrm{~V}^{5+}{ }_{4} \mathrm{O}_{20}$ and $(\mathrm{enMe})_{2} \mathrm{Zn} \quad\left(\mathrm{VO}_{3}\right)_{2} \cdot 2 \mathrm{H}_{2} \mathrm{O}$ containing pillared/layered structure," in Proceedings of the German-Thai Symposium on Nanoscience and Nanotechnology, Bangkok, 2007, pp. 63-68.

[16] Bruker, SMART (Version 5.625) and SAINT (Version 6.26a), Bruker Analytical X-ray Systems Inc., Madison, Wisconsin, USA, 2001.

[17] E. V. Murashova, V. K. Velikodnyi, and V. K. Trunov, "Structure of the double pyrovanadate $\mathrm{K}_{2} \mathrm{MgV}_{2} \mathrm{O}_{7}$," Z. Neorganicheskoi Kbimii, vol. 33, no. 6, pp. 1593-1595, 1988.

[18] T. S.-C. Law and I. D. Williams, "Organic-directed synthesis of manganese vanadates with variable stoichiometry and dimensionality: 1-D [(Hen $\left.)_{2} \mathrm{Mn}\left(\mathrm{VO}_{3}\right)_{4}\right], 2-\mathrm{D} \quad\left[\left(\mathrm{H}_{2} \mathrm{en}\right)_{2}\left[\mathrm{Mn}\left(\mathrm{VO}_{3}\right)_{4}\right]\right.$, and 3-D $\left[\left(\mathrm{H}_{2} \mathrm{en}\right)\left[\mathrm{MnF}\left(\mathrm{VO}_{3}\right)_{3}\right]\right.$," Chem. Materials, vol. 12, no. 1, pp. 2070-2072, 2000.

[19] X. Zhao, Y. Zhang, and Y. Wang, "Synthesis of propylene carbonate from urea and 1,2-propylene glycol over a zinc acetate catalyst," Ind. \& Eng. Chem. Res., vol. 43, no. 15, pp. 4038-4042, 2004.

[20] B. C. Chakoumakos, R. Custelcean, T. Kamiyama, K. Oikawa, B. C. Sales, and M. D. Lumsden, "Structural modulation in $\mathrm{K}_{2} \mathrm{~V}_{3} \mathrm{O}_{8}$," J. Solid State Chem., vol. 180, no. 3, pp. 812-817, 2007.

[21] H. B. Yahia, E. Guadin, and J. Darriet, "Crystal structures of new pyrovanadates $A_{2} \mathrm{MnV}_{2} \mathrm{O}_{7}(\mathrm{~A}=\mathrm{Rb}$, K)," Z. Naturforschung B, vol. 62, no. 7, pp. 873-880, 2007.

[22] S. Krachodnok, "Syntheses and Structural Studies of Organically Modified Main Group Vanadates," Ph.D. thesis, Suranaree University of Technology, 2010. 
